\title{
Informational roles and information needs of formal caregivers at child welfare institutions in Malaysia
}

\author{
Nurul Hazimah Ab. Durahman, A.M.K.Yanti Idaya* and A.Noorhidawati \\ Department of Library and Information Science, \\ Faculty of Computer Science and Information Technology, \\ University of Malaya, Kuala Lumpur, MALAYSIA \\ e-mail: zimahabd@siswa.um.edu.my; *yanti@um.edu.my (corresponding author); \\ noorhidawati@um.edu.my
}

\begin{abstract}
This study investigates the information needs of formal caregivers of child welfare institutions through the landscape of their roles and tasks. A case study approach using purposive sampling of three children welfare institutions was conducted with a total number of 10 participants. Data were collected through a series of interviews and two focus groups. Qualitative data were analysed using NVivo. Open coding and thematic coding were used to generate themes on the informational roles and needs of the caregivers. The caregivers perform their roles as guardian, counsellor, and administrator which involve informational roles as a monitor, disseminator and spokesperson of internal and external information for the institution. Each role requires specific information in order to fulfill their tasks such as information on the children's background, daily information required, past education, future education (including sex education) and career path, monitoring of former children, disciplinary action taken on misbehaving children, information related to sports and leisure activities, safety, health as well as children rewards. This paper is significant to this specific community (caregivers of child welfare institutions) in order to understand their information needs, based on the actual caregivers' roles and tasks. The findings would be useful as a benchmark in providing better information services for the caregivers to perform their roles and tasks in managing children at risk.
\end{abstract}

Keywords: Caregivers; Informational roles; Information needs; Children at risk; Child welfare.

\section{INTRODUCTION}

Neglected children in this world had experienced various problems arising from their surroundings. These problems include physical and sexual abuse, uncontrolled behaviour, bad influences and drug abuse, cultural differences, poverty, and promiscuity. Although each issue may occur in isolation, children often become victims of more than one type of issues. These issues are indeed very alarming, as this social phenomenon is shown to be rampant and growing. According to McDonald and Garrow (2000) children who are below 18 and in danger or at risk that affect their personal wellbeing and environment, including related areas which prevent them from achieving their potential, are called children at risk. These children at risk require special guidance and should be given equal rights as other children in the world. The legislation Malaysian Children Protection Act (1991) defines that every child has the right to get protection and assistance in any circumstances without 
differentiation by race, skin color, gender, language, religion, background or physical, mental and emotional disabilities, and status (Malaysia 1992).

Institutionalizing children at risk is one of the solutions available to prevent and protect these children from becoming victims of poverty, abuse, or any future misconduct. The institution acts as a temporary shelter for these children by giving them guidance and services in terms of educational, emotional, physical, psychological, social, spiritual, moral support, and ethics. This interaction should be heavily supervised and guided by trained and motivated caregivers. However, according to the Convention on the Rights of the Child (CRC) in Article 20 (UN General Assembly 1989), placing children in these institutions is the last resort when there are no more options available. It is only suitable for a very small minority of children (Institutional Care: The Last Resort 2014). In Malaysia, there are a number of private or public children welfare institutions. According to the Malaysian Social Welfare Department, there are six public children welfare institutions in Malaysia, which are the Children Homes Welfare, Girls Protection Shelter, Boys Approved School, Home Shoots of Hope (Rumah Tunas Harapan), Moral Dormitory (Asrama Akhlak), and the ATIP Shelter House (Rumah Perlindungan ATIP). These institutions are housing different types of children at risk such as those under court order, with uncontrolled behaviour, and are neglected. These welfare institutions are subject to the Laws of Malaysia Act 611 Child Act 2001 (Malaysia 1992). This act allocates the power and duties of appointed social welfare officers (including social welfare assistants), director, deputy director and counsellor as Protectors under Section 8.

A protector is a formal caregiver who is the most responsible person to look after someone's health and well-being, while a secondary caregiver provides supplemental or intermittent care and support, and a tertiary caregiver provides a helping hand in doing tasks such as shopping and housework (Cumming 2011). According to Czuba (2015), formal caregivers are those who are paid to take care of people who need long term care. This includes caring for the people who reside in nursing facilities, private hospitals, rehabilitation centres, and people with intellectual impairment. Their main role is to help people carry on their daily life activities. The caregiver can be expected to manage the physical, practical, emotional and spiritual needs of a loved one, while continuing to manage his or her own life (Team OncoLink 2018). Personal support workers have been identified as "the backbone" of long-term care (Noelker 2001), as these are the workers that provide the vast majority of direct hands-on care in long-term care facilities. They are marked to be the group whose services will have the highest growing demand in future.

This study focuses on caregivers at children welfare institutions. Children welfare institutions can be regarded as an alternative care for children who are vulnerable and are involved in disadvantaged situations for various reasons, and who need to be separated from their parents or guardians. These institutions act as temporary shelter for these children by giving them guidance and services in terms of education, emotional, physical, psychological, social, spiritual, moral support, and ethics. All these services are heavily supervised and guided by trained and motivated caregivers. In addition, caregivers at children welfare institutions comprise counsellor, guardian and administrator; they have an informational management role. These informational roles include a function of a caregiver as a monitor, disseminators and spokesperson of internal and external information for the organization (Mintzberg 1971). According to Choo (2002) the informational management roles involves gathering relevant information, processing and analysing information, disseminating and sharing information and using information for 
decision making. In order to prepare themselves as caregivers, the information needs for this group of people must be addressed.

Children at risk require information from their caregivers. The information needs of caregivers could be different based on the people they take care of. For example, the information needs of caregivers of orphanages might not be the same as the information needs of caregivers taking care of older folks. There is likely an increased need of some form of assistance for children at risk since they are different from normal children and they may require special treatment. The information provided by their caregivers can act as a catalyst tool in providing hope to the children. As caregivers, they need to have wide knowledge on information related to the children's welfare, especially in terms of the children's needs so that both parties can acknowledge each other. Caregivers are considered part of the special community which works at welfare institutions; therefore, they are required to get information that is specific for them.

Numerous conditions that deter the caregivers' effectiveness of getting information at child welfare institutions have been found in several studies (Department of Social Welfare (DSW) and UNICEF 2011; Groark and Mccall 2011; Audit Scotland 2010). Among others are lack of professional training (Heron and Chakrabarti 2002; McCall, 2013; Wright et al. 2014; Sukeri et al. 2017), and support (Van IJzendoorn et al. 2011; Department of Social Welfare (DSW) and UNICEF 2011; Ravenswood, Douglas and Teo 2014). Over the last decade, the government has taken a significant approach to improve the child protection system by enacting the Child Act of 2001 (Act 611) (Malaysia 1992). This act has allocated for the rights of caregivers. Although the Child Act 2001 (Malaysia 1992) had mentioned the right of caregivers, problems such as less interaction, lack of training and support do affect the caregivers. This is essential particularly when they encounter problems in taking care of these children, what is the actual needs by these children, and how they seek information in order to fulfill these needs. Therefore the focus of this study is to develop an understanding of the information needs of caregivers at children welfare institutions.

\section{LITERATURE REVIEW}

Child caregivers have historically been harshly judged for their failure to protect children (Utting 1993), although they are given the responsibility to deal with thousands of people in terms of their private lives, sensitivity, and importance (Utting 1993). Dealing with children can be particularly challenging, especially in terms of giving them support, treatment, protection and care. In such situations, caregivers must ensure that they understand their roles and responsibilities in supporting these children. According to Marleen et al. (2017), men and women who work in childcare are likely to share important pedagogical-oriented traits that have made them decide to become professional caregivers, even before they entered any vocational training centre (Marleen et al. 2017). Caregivers need to be creative, do things unconventionally and think outside the box due to limitations faced by them when providing care for these children. Meeting with child welfare professionals who work with traumatized children may help to know more about their distressing experiences. Information related to the traumatic experiences of the children are gathered through evidence-based evaluations and training sessions which is important to later provide appropriate assistance needed by the children (Lieberman 2011). Utting (1997) reported young children under child protection and welfare were longing close relationship with their caregiver hence it is important for the children that the caregiver acts as the child's advocate within the welfare organization. 
Mnubi-Mchombu, Mostert and Ocholla (2009) conducted a research on the informationseeking behaviour of orphaned and vulnerable children's caregivers in the rural and urban areas of Namibia through focus group discussions. The results showed that the rural residents expressed their need for information on educational support, psychological and counselling services, childcare, and job opportunities. In urban areas, information on educational support and the establishment of small businesses were featured as prominent needs of the caregivers. Kiilu and Kiilu's (2015) study on the information access of urban workers in Nakuru city, Kenya involved interviewing 12 respondents working in the child social welfare system. These respondents mainly sought information on questions regarding the background and main causes of children on streets, information on potential donors, and adoptive parents. Additionally, 18 percent of them sought information regarding areas that were relevant such as child rights and child abuse. Another study by Zoontjes (2015) in Netherlands on the information-seeking behaviour of child right professionals mentioned that these professionals seek information on related procedures/regulations, policies, facts, and children's rights.

Caregivers play an essential role in helping children and teenagers recover from traumatic events, understanding the information needs of the children they care would be useful. Ndiku (2015) investigated how information needs of school children in Kibera information settlement, Nairobi, Kenya were met. The findings showed that the information needs of children varied. The children need to improve their knowledge regarding sex education, social integration, moral value, pollution, social interaction, resolution of conflict, safety information, gender, role model and mentorship, art creativity, and extracurricular activities. These children themselves stated that they need information on problem-solving skills, moral teachings, environmental care, and the impact of drug use, improvement on academic performance, life skills, and children's right. Grove et al. (2017) investigated information needs of children who were looking after their parents with mental illness. The data indicated that the children needed information and knowledge about their parents' illness such as on psychological and behavioural, information to cope with the illness, and safety.

\section{OBJECTIVES AND METHODS}

The aim of this study was to investigate the informational roles and information needs of formal caregivers. To address this aim, the following research questions were outlined: (a) what are the informational roles and tasks of formal caregivers at children welfare institutions?; and (b) what are the characteristics of the information needs of formal caregivers at children welfare institutions?

This research employed a qualitative enquiry method to establish the roles, tasks and information needs of formal caregivers at children welfare institutions. The qualitative research approach was employed by means of interviews and focus group sessions purposively set up to gather in-depth information. Three different types of welfare institutions in Klang Valley area were chosen as case settings (Table 1) using the purposive sampling technique as follows:

(a) The geographic locations of all selected institutions are within reach of the researchers to minimize cost for travelling and to make it convenient for the researchers to establish prolonged engagement with the respondents.

(b) The selected children welfare institutions are operated under the care of the Department of Social Welfare, Malaysia. 
(c) The selected institutions house children of various ages and include both males and females which made it possible for the researchers to study the possibility of different roles and tasks of children caregivers that might reflect different information needs.

The three types of the welfare institutions and the description of the selected case setting are as follows:

(a) Boys' Approved School - This approved school was established in 1947 in Sungai Besi, Kuala Lumpur, under Section 65 of the Child Act 2001 for the education, training, and detention of the children. Its establishment serves two objectives: (i) teaching the children to build a positive attitude, and (ii) shaping the children into strong persons and equipping them with skills which can help them to act independently in the society. The admission of the children is done under court order according to Paragraph 91(1)(f) or Section 46 of Child Act 2001.

(b) Children Welfare Home - This institution was established in 1964 for the preservation and protection of children as listed under Section 54 of the Child Act 2001. It is located in Cheras, a suburban city in the Federal Territory of Kuala Lumpur. The purpose of this institution is to provide protection and recovery for the children to ensure that they are physically and emotionally healthy in a harmonic and safe environment. The services provided are care and protection, guidance and counseling, education (including religious and moral education), indoor and outdoor activities, leisure, and medical and health treatment. The admission of the children is done under court order according to Paragraph 30(1)(d) of Child Act 2001.

(c) Girls' Protection Shelter - This girls' institution was established under Section 55 Child Act 2001 for the rehabilitation and care of girls below 18 who were exposed to moral danger and had been involved in sexual exploitation as child prostitutes. It is located in Kajang, Selangor. The objectives of this institution are to give protection and rehabilitate girls who are exposed to sexual exploitation and violence through social, mental, spiritual, and moral development in addition to teaching suitable life skills. The admission of children is done through court order as stipulated under Paragraph 40(3) (a) or Section 46 or the abused may applied personally as prescribed under Subsection 41(1) of the Child Act 2001.

\section{Data Collection Procedures}

This study had obtained the ethical consent from the University of Malaya and the Department of Social Welfare, Malaysia. Data were collected through a semi-structured interviews and focus group sessions. Semi-structured interviews were used in this study as the interview questions were prepared ahead of time, and this allowed the interviewer to be prepared and able to internalize all the information received to enable the interviewer to be competent when conducting the interview (Cohen and Crabtree 2006). The focus group was used to triangulate and make the data more complete thus enabling better understanding of the phenomenon under study.

Seven interview and two focus group sessions were conducted at the three selected children institutions. The participants comprised protectors (under Child Act 2011) or caregivers who were responsible for taking care of these children. They included Social Welfare Officers (Principal and Counsellor) and Social Welfare Assistants (Table 1). A purposive sampling technique was used directly to select the caregivers. The inclusive characteristics used to choose the suitable caregivers are as follows:

(a) Participants must work with these children or are involved with their affairs, activities, and issues. 
(b) Participants must be willing to participate throughout the duration of the study and should have good communication skills so that the researchers would be able to understand the respondents' thoughts and opinions.

Appointments were made before the interviews through phone calls. During the appointment, an introductory session was conducted to brief the respondents on the purpose of the study. The consent letter was read out and given to the respondents. This was important so that the participants could understand the purpose of the study. Each participant responded positively when they were requested to sign the consent letter.

Table 1: Demographics Information of Participants

\begin{tabular}{|c|c|c|c|c|c|}
\hline Institution type & Participants* & Position & $\begin{array}{l}\text { Education } \\
\text { Background }\end{array}$ & $\begin{array}{l}\text { Interview } \\
\text { Session (S) }\end{array}$ & $\begin{array}{l}\text { Focus Group } \\
\text { (FG) }\end{array}$ \\
\hline \multirow[t]{4}{*}{$\begin{array}{l}\text { Boys' Approved } \\
\text { School }\end{array}$} & Osman & Principal & $\begin{array}{l}\text { Bachelor } \\
\text { Degree }\end{array}$ & S1 & FG1 \\
\hline & Salman & Counsellor & $\begin{array}{l}\text { Bachelor } \\
\text { Degree }\end{array}$ & S2 & FG1 \\
\hline & Ali & Social Welfare Assistant & Certificate & S3 & FG1 \\
\hline & Siddiq & Social Welfare Assistant & Certificate & S4 & FG1 \\
\hline $\begin{array}{l}\text { Children } \\
\text { Welfare Home }\end{array}$ & Aisyah & Principal & $\begin{array}{l}\text { Bachelor } \\
\text { Degree }\end{array}$ & S5 & Not involved \\
\hline \multirow{5}{*}{$\begin{array}{l}\text { Girls' Protection } \\
\text { Shelter }\end{array}$} & Khadijah & Social Welfare Assistant & Certificate & S8 & Not involved \\
\hline & Fatimah & $\begin{array}{l}\text { Counsellor/Psychology } \\
\text { Officer }\end{array}$ & $\begin{array}{l}\text { Bachelor } \\
\text { Degree }\end{array}$ & S6 & Not involved \\
\hline & Zainab & Social Welfare Assistant & Certificate & S9 & FG2 \\
\hline & Raziah & Social Welfare Assistant & Certificate & S7 & FG2 \\
\hline & Kassim & Social Welfare Assistant & Certificate & S10 & FG2 \\
\hline
\end{tabular}

*Pseudonym, gender reflected by the name given.

The interview sessions were conducted in a quiet and comfortable room in the respective institutions. Informed consent which explained the basis of the research and notified that participation is voluntary was provided during the data collection sessions. Interviews and focus group sessions were conducted in the Malay Language, the official language and language of instruction in Malaysian schools. Each interview lasted between 30 and 45 minutes, while it took 45 to 90 minutes for the focus group sessions. Only two focus group session were conducted for Boys' Approved School and Girls' Protection Shelter. Focus group session for Children Welfare Home was unable to be conducted since only two participants were willing to take part in the session.

All these sessions were audio-recorded and data were transcribed before analyzed together with the background information of each respondent. Both digital audio recorder and smart phone were used during each interview because they provided accurate transcription and reduced the risk of lost data. These devices were used to fully record the actual conversation to avoid any false information thus allowing the researchers to concentrate on what was said by the caregivers. Member checking was used as a means of verifying meanings and gathering additional information.

Data in the digital recorder and mobile phone were transcribed using Microsoft Word. In the transcripts, the researcher decided to use pseudonyms for the respondents. Checking and editing was the second step where the researcher identified and recorded the themes suitable with the topics. All data were imported into the NVIVO 11 software for analysis. Categories and themes related to the caregivers' informational roles and needs were then identified and coded. 


\section{Theoretical Lens}

Caregiving is a professional work and therefore, this study was guided by the Information Needs Model which specifically applies to professionals at work. This study used Leckie, Pettigrew, and Sylvain's (1996) model because the model applies the information needs model for professionals such as engineers, lawyers, and health care personal. Leckie, Pettigrew, and Sylvain's (1996) model is based on six components: work roles, tasks, characteristics of information needs, awareness of information, sources of information, and outcomes. This study focuses only on the first three components: work roles, tasks, and characteristics of information needs. Work roles generally lead to certain tasks which prompt specific information needs and this notion was supported by Niedźwiedzka (2003) and Vakkari (1999) who reported that tasks identified by workers, performance and consequent information needs are determined from these tasks. According to Leckie, Pettigrew, and Sylvain (1996), information needs arise from situations pertaining to specific tasks that are associated with one or more of a professional's work roles. The Information Needs Model used as the theoretical lens of this study is believed to be able to address the research questions on caregivers of children at risk. The model was chosen because it is applicable to all professionals. It incorporates both roles and tasks of work as well as information needs of formal caregivers of children at social welfare institutions which are important for this study.

\section{RESULTS}

As this study focused on work roles, tasks and information needs in the Information Needs Model used, the researchers created themes based on the data which were analyzed using open and thematic coding. Figure 1 depicts the themes which emerged from the data which have helped to address the research questions.

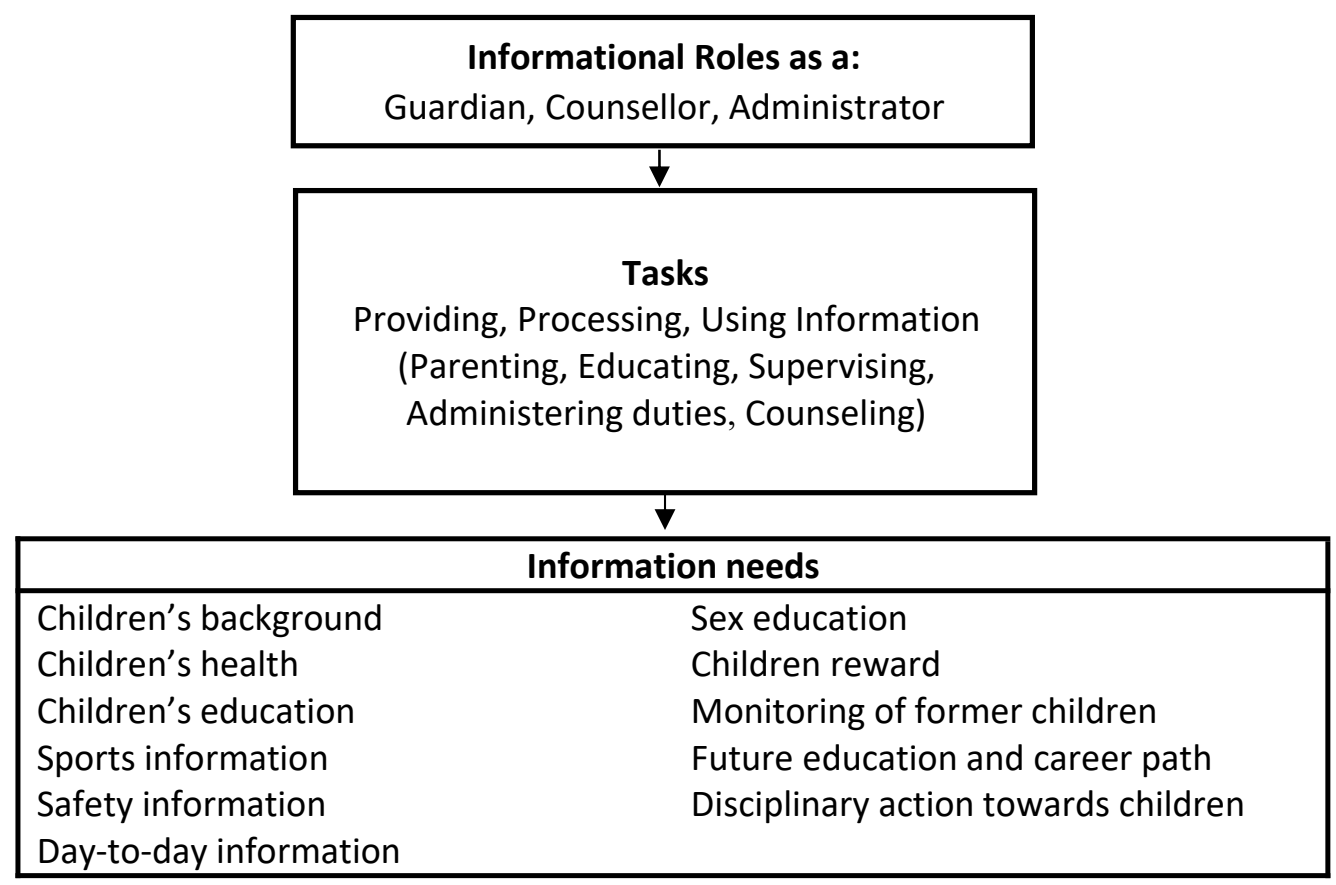

Figure 1: Themes Emerging from the Data 


\section{The Informational Roles and Tasks of Formal Caregivers at Children Welfare Institutions}

Leckie, Pettigrew, and Sylvain (2016) pointed out that professionals have work roles such as being administrators/managers, research, service providers, and educators. Role is defined as a set of activities accomplished by an individual or group related to an organization (Huckvale and Ould 1995). There are tasks embedded to the roles that require information needs to be fulfilled. In this study, the work roles of caregivers are described in order to lead to such tasks and subsequently their information needs. Figure 2 shows a summary of the three main formal caregiver's roles at children welfare institutions, that of a guardian, counsellor, and administrator, their related task according to the roles and informational roles when handling information in completing their responsibility.

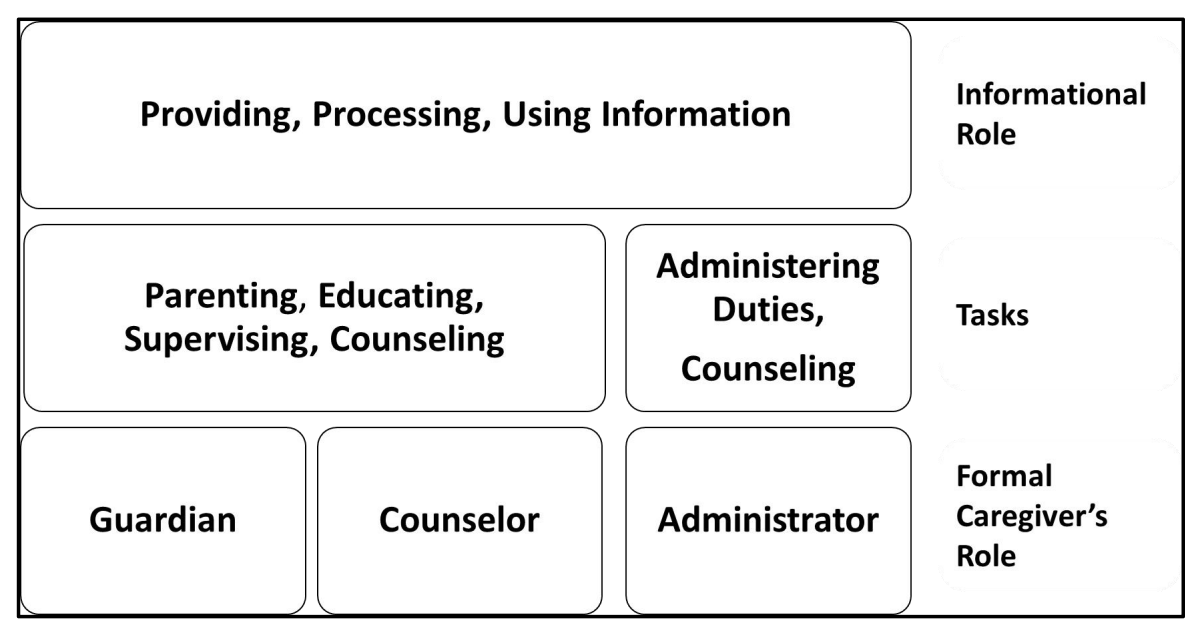

Figure 2: Informational Roles of Formal Caregivers

\section{(a) Guardian}

The Convention on the Rights of the Child (CRC) in Article 20 refers to legal guardians "as a key element of a protection system for children who are temporarily or permanently deprived of their family environment and cannot have their interests represented by their parents" (UN General Assembly 1989, Article 5: 168). Thus, the role of a guardian is the principal role of caregivers at institutions. It is related to providing information to the children who need help and involving themselves in daily interactions with children and their routine activities. In performing this task, the guardians personify themselves as a monitor to acquire internal and external information regarding the issues that are affecting especially the children, and the organization.

Guardians are very close with the children as they provide them food, shelter, education and reward, as well as understand each of their characters and needs. As indicated by a participant: "Community Welfare Assistants will know the character of the children... what they (the children) did yesterday as they deal with them every day." (Zainab, Social Welfare Assistant, FG2, Girls' Protection Shelter)

\section{(b) Counsellor}

A counsellor assists a person who has difficulty in identifying his/her problem by providing solutions and solving it at the end (Alavi, Boujarian and Ninggal 2012). The counsellors at these institutions performing their role as a disseminator. They received and then disseminated/transmitted the internal and external information within the organization 
particularly to the children and other caregivers. These institutions provide counsellors who offer help to both the children and other caregivers in dealing with difficulties especially in terms of emotions, family problems, mental health, and trauma. Children seek counsellors' help and support to deal with their problems. The following statements reflect caregivers' role as a counsellor in disseminating the information:

"Before the children have the examination, we at times call speakers from education department or teachers who teach here to give talk. Sometimes, our staff will give explanation about the exam because we do have a unit in charge of education." (Fatimah, Counsellor, S6, Girls Protection Shelter).

"In terms of HIV (Human Immunodeficiency Virus), AIDS (Acquired Immune Deficiency Syndrome), for sex education, we usually call PKN (Pusat Khidmat Nasihat) or KKM (Kementerian Kesihatan Malaysia) and the Ministry of Health Malaysia to come and brief the children." (Salman, Counsellor, S2, Boys Approved School).

\section{(c) Administrator}

Administrator refers to an individual involved in the planning, organizing, directing, controlling, and evaluating activities of major units (Arizona Board of Regent 2009). There are two administrative positions in a child welfare institution: principal and deputy principal. They serve as a spokesperson to represent the organization and provide outsiders with information about the organization. The following statement highlighted that the specific duty of a principal is to plan and conduct meetings in the institution with the staff, therefore the information was used for decision making purpose: "Before fasting, we are going to have a meeting. We are going to have one meeting in September. That is all at the institution's staff level...but there will be meetings for the departments...for community welfare assistants, they even have a discussion apart from the meeting." (Aisyah, Principal, S5, Children Welfare Home).

Hence, in carrying out the informational role which involves processing information, the guardian is a monitor who regularly seeks information, the counsellor is a disseminator who communicates potentially useful information and the administrator is a spokesperson who represents and speaks for the organization. The three informational roles of caregivers would be analyzed in accordance with the tasks depicted in the Information Needs Model (Leckie, Pettigrew and Sylvain 1996) in order to understand their information needs.

\section{Tasks}

Task is known as a work that needs to be done whether it is done regularly, unwillingly, or with difficulty. The three formal caregiver's roles have the following five tasks: parenting, educating, supervision, administration duties, and counseling, and each is associated with providing, processing and using information as shown in Figure 2. Findings indicated that the tasks were reported to be overlapped with the informational roles the caregivers provided.

\section{(a) Providing information in educating the children (as Guardian and Counsellor)}

Educating means giving intellectual, moral, and social instruction to (someone) (Oxford Dictionaries). A caregiver's tasks involve interaction with children whenever the children have questions related to their homework, studies, and sometimes information from resources that inaccessible to them such as using the Internet. In some cases, the participants would refer to other caregivers (peers) to answer the children's inquiries, in terms of doing their homework because they are not familiar with the subject, or due to time constraints: "Usually, we (caregivers) will help them if we are able to answer it 
(homework); however, sometimes we cannot help them due to time constraints, therefore, we refer them to another officer (caregiver) to solve it." (Khadijah, Social Welfare Assistant, s8, Children Welfare Home).

Taking care of the children's education is also part of the caregivers' responsibilities. Their responsibilities involve encouraging the children to study because some children at the institutions are not keen towards education even before they come to reside in the institutions. However, there are also students who are interested to know more about education opportunities, offered by other organizations such as Majlis Amanah Rakyat (MARA) as remarked by a participant: "...the institution itself will provide information on MARA, especially the level of education the children should enter." (Ali, Social Welfare Assistant, S3, Boys' Approved School).

There are times when the caregivers have to use the Internet to help the children under their care as these children are prohibited from gaining access to the World Wide Web at the institution due to the rules and regulation of not exposing the children to the public (online or offline) for their own safety: "We will provide what she (children at risk) wants, for example, if she wants information related to SPM syllabus, the officer who is sitting at the counter will help her to search the Internet for that information." (Fatimah, Counsellor, S6, Girls Protection Shelter).

(b) Providing and using information for parenting purpose (as Guardian and Counsellor) Parenting means purposive activities aimed at ensuring the survival and development of children (Hoghughi and Long 2004). Since the caregivers are the only ones who take care of the children's development and spend most of their time with the children, it is not surprising that these children regard the caregivers as their parents. The children at the Children Welfare Home and Girls' Protection Shelter call their female caregivers "emak", which means mother: "They (children) will come to me and ask "Emak (caregiver), how to do this?" (Zainab, Social Welfare Assistant, FG2, Girls' Protection Shelter).

As parent themselves, the participants acknowledged having developed a strong bond with the children. There are even outing programmes organized by these institutions to establish and strengthening the bonding between caregivers and the children, as reported below:

"The caregivers here know when it is time for the children's outing. We (institution) encourage them (caregivers) to go out with the children since it is compulsory; this is to create bonding between the caregivers and the children. This outing is actually a compulsory programme." (Aisyah, Principal, S5, Children Welfare Home).

"Yes, we went for outing together (children and caregiver). We watched movie in the school area and sometimes we went out to watch movie in cinema and theater." (Salman, Counsellor, S2, Boys' Approved School).

\section{(c) Providing and using information in supervising the children (as Guardian)}

Supervision is defined as watching over the work of another with the responsibility of ensuring its quality (Kadushin and Harkness 2014). A caregiver is responsible for supervising children in accordance with the provisions of the Child Act. It is the caregivers' responsibility to explain about the institution on the children's first day of residing in the institution. The information given during the briefing is mostly about the children's daily life and the rehabilitation process, health, schedule, grading system, school rules, rewards given when they obey the rules and the punishment given if they break the rules. As 
illustrated by a participant from the Boys' Approved School: ".... the officer (caregiver) who is in charge explains a little bit of information on the Boys' Approved School .... after that he will explain the daily activities which are usually done by the new children when they enter here...more explanation are given on what should not be done here." (Siddiq, Social Welfare Assistant, S4, Boys' Approved School).

(d) Processing and using the information for decision making related to children welfare (as Administrator)

Administration is defined as the process of managing and being responsible for the running of a business and organization (Lexico Powered by Oxford 2019). In this study, the caregivers' tasks involve supervising the residents, managing rules and regulations, attending meetings, and solving issues. Most of the respondents who carried out the administrative duties are the principal or head of the institution. The duties do not only focus on managing the children, but also the residents at the institutions. The statement below reflects that the participant had to observe and admonish caregivers' perception by giving them training and advise when they have problems related to their work:

"... whenever I see that there is something wrong, I will be the one who give the training ...not as perfect but at least we can change his/her perception." (Osman, Principal, S1, Boys' Approved School).

(e) Providing, processing and using the information in counseling sessions (as Guardian, Counsellor and Administrator)

A counsellor's tasks are to examine the issues faced by the residents at the institution related to emotional, feeling, and psychological treatment and services besides guiding the children and caregivers in dealing with their hardship. One of the participants who is a counsellor mentioned that whenever a child under the guidance of a caregiver is having a problem, the caregiver would refer to the counsellor to get advice on how to deal with the child, or the counsellor will conduct a counseling session with the child: "Every week I conduct a counseling session with the students. Normally....it takes one hour for each student. I record all the information gathered from the student and write a report." (Salman, Counsellor, S2, Boys' Approved School).

Regular sessions of counselling and guidance are provided by the guardians and administrators indicated in the following verbatims:

.. they (caregivers) will not share a child's problem among themselves (caregivers), they only share it with me. I am going to be in charge of handling the problem and I will do a counseling session with the child." (Raziah, Social Welfare Assistant, FG2, Girls' Protection Shelter).

"We have SOP in our CMS...Client Management System. So... we follow the SOP. It means, if there is a case of fight, we investigate. If there are injured students, we send them to the hospital first. After that we conduct a counselling session among me, counselor and students who involved in the case." (Khadijah, Principal, S8, Children Welfare Home).

\section{Characteristics of Information Needs of Formal Caregivers at Children Welfare Institutions}

To comprehend the characteristics of information needs of formal caregivers, the participants were asked about their information needs. They presented their opinions, views, and perception regarding their information needs. According to Leckie, Pettigrew, and Sylvain's (1996), it is important to obtain the information needs related to key work roles. Eleven (11) main themes that reflect the characteristics of information needs emerged from the data, namely; (i) children's background, (ii) day-to-day information, (iii) 
children's education, (iv) future education and career path, (v) sex education, (vi) monitoring of former children, (vii) disciplinary action towards children, (viii) sports information, (ix) safety information, (x) children's rewards, and (xi) children's health. Figure 3 presents these characteristics in relation to the roles and tasks performed by the caregivers. Some of the characteristics of information needs among caregivers are shared within two or three work roles, for providing example day-to-day information is performed in all three roles.

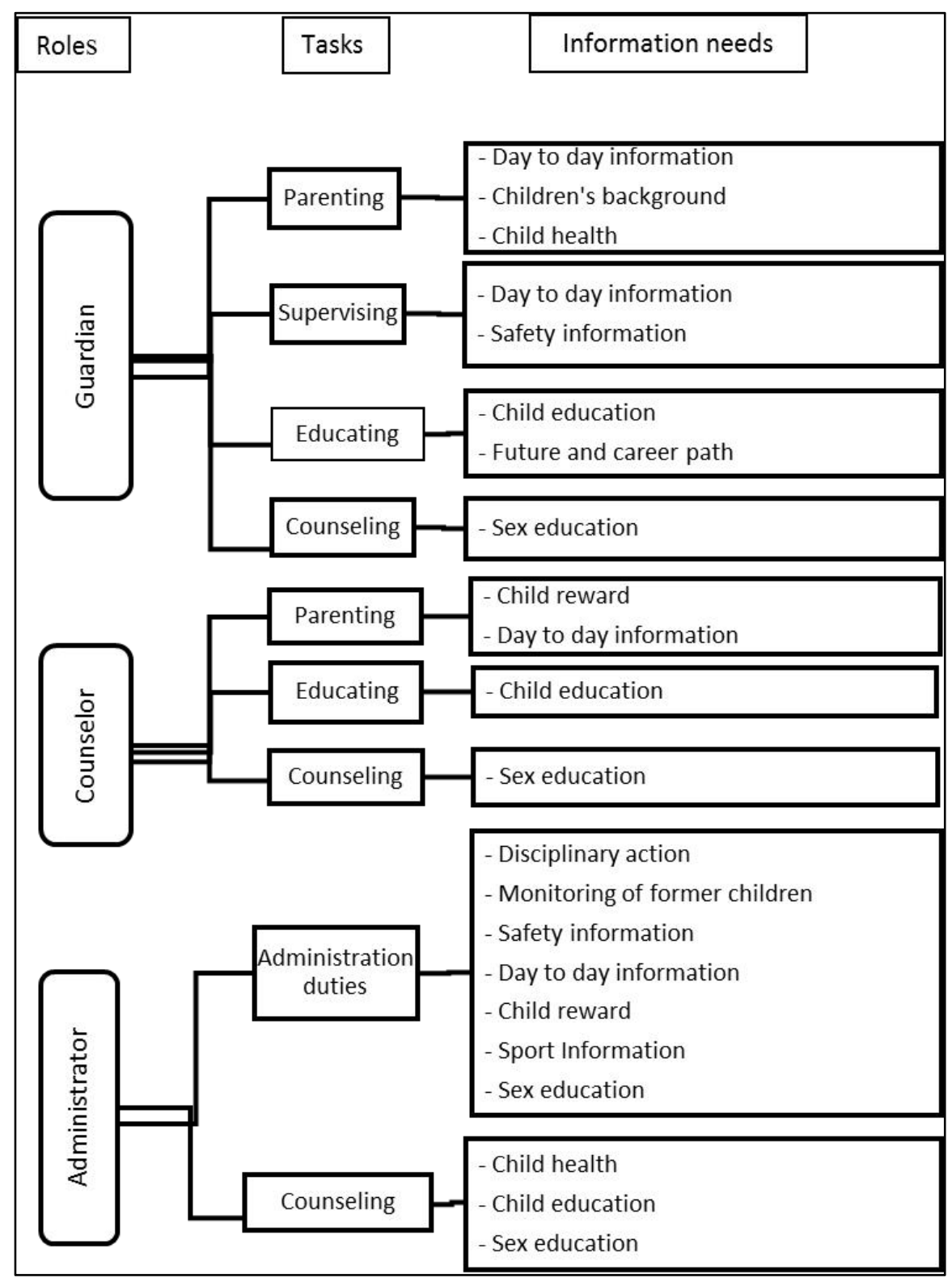

Figure 3: Summary of the Characteristics of Formal Caregivers' Information Needs

(i) Children's background (Guardian - Parenting)

There is a need to gather information on the children's background before their admission to the institutions. This information may include the children health conditions. As a normal practice the caregivers conducts an informal interview or casually asked the young children (below 12 years old) to gather information related to their background and reason why they are being placed in the institution. A participant described, "At first, we 
(caregivers) look at his/her (child at risk) age level. Let's say if his/her (child at risk) age is twelve, we will normally interview him/her (child at risk) as usual, like asking his/her (child at risk) name and the case that made him/her (child at risk) to reside here. We (caregivers) ask something that he/she (child at risk) can answer. (Khadijah, Social Welfare Assistant, S8, Children Welfare Home).

The need for information on the children background is important in order to understand the children's condition such as their physical, mental and emotional state in developing trust and close relationship at later stage. This information is normally supported with reports from the court order and probation.

(ii) Day-to-day information (Guardian - Parenting and Supervision; Counsellor - Parenting; Administration - Administration duties)

Caregivers are responsible to seek information related to their duties particularly when they are new to the particular childcare institution. Most of the information received through communication with peers are about their daily work routine and type of activities conducted for the children at the institution. Handling children requires endurance, passion, and motivation. The caregivers need information to perform their daily tasks effectively as guardians, counsellors, and administrators. Handling children at risk who come from different backgrounds and court cases are challenging. The following verbatim statement shows the need for day-to-day information by a senior Community Welfare Assistant who had previously worked at an elderly home: "I ask a lot of questions related to my responsibility in taking care of the children. The work flow here is quite different from the elderly home; therefore, I need to ask a lot." (Siddiq, Social Welfare Assistant, S4, Boys' Approved School).

Day-to-day information is important to the caregivers in order to facilitate and guide the children at the institution. The caregivers who play the role as a counsellor must understand the children's mental, physical and emotional conditions. As mentioned by one of the participants during a focus group interview, children come to the caregivers to express their problems: "There are also children who told me that they miss their family." (Siddiq, Social Welfare Assistant, FG1, Boys' Approved School).

The caregivers have to be close to the children. At times the children themselves approach to the caregivers to talk about their problems. Hence, training is necessary to help the caregivers to enrich their knowledge in handling these children. This is supported by one of the participants who mentioned: "recently, I have requested to attend a course related to psychology and counseling..." (Siddiq, Social Welfare Assistant, S4, Boys' Approved School).

(iii) Children's education (Guardian - Educating; Counsellor - Educating; Administration Counseling)

In these institutions, some of the children at risk are not interested to attend school to study. Therefore, the institutions are responsible to ask these children either they want to continue their study and go to the normal academic stream or opt for technical or vocational courses. According to a counsellor, most of the children had not gone to school before entering the institution: "A majority or 99\% of them did not go to school." (Salman, Counsellor, S2, Boys' Approved School). Children who are interested in vocational education are encouraged to attend related courses provided by the institution as Salman reported: "we conduct a few vocational courses at the institution... the in-house course that we have is newly recognized by SKM level 1 is on automotive course." (Salman, Counselor, S2, Boys' Approved School). 
As guardians, the caregivers must understand the children's interest in education. To obtain this information, the children may refer to the institution and their peers. At times, administrators invite external speakers to the institutions to give talks to the caregivers about possible education opportunity and path for the children, as acknowledged: "We sometimes invite speakers from the education department or teachers (who teach the children) to talk about the possible education opportunity available for them." (Fatimah, Counsellor, S6, Girls' Protection Shelter).

Since the children are under protection, they are not allowed to have any contact with the outside world including communication via the Internet. Any information to be obtained from the Internet has to be gathered by the caregivers as they are the only ones who can have access to the Internet. The following statement shows an example of caregivers using the Internet to help children to answer inquiries about education:

"....if she wants information on related to SPM syllabus, the officer who is sitting at the counter will help her by searching the internet for that information." (Fatimah, Counsellor, S6, Girls Protection Shelter).

(iv) Future education and career path (Guardian - Educating)

Caregivers need to have knowledge about future education and career path for the children at risk. This is necessary in order to provide the children with required and correct information about their future education and career as they are about to be released from the institutions. The following statement indicated that the caregivers used a career interest test to identify the children's future career interest:

"I do a test... for example, a career interest test. From the test, the children will know their interest, what are their career path and what are the requirements needed. We will try to provide the needed information" (Raziah, Social Welfare Assistant, S7, Girls' Protection Shelter).

This information is important for the caregivers to assist and guide the children of the various options in their future education as mentioned by Salman: "They do not know about the opportunities available to further their studies, so we (caregivers) are the ones who are responsible to inform them... for example... if he takes Giat Mara, what are his future opportunity? If he takes SKM, what can he do later? If he takes SLN, what to do next? If he becomes a workshop apprentice, what furniture can he make?" (Salman, Counsellor, FG1, Boys' Approved School). The institutions also made some arrangements for a site visits to organizations that provide support to the children's future education: "We have made a visit to ALAM in Melaka, which is the Institute of Marine Academic Training." (Salman, Counsellor, FG1, Boys' Approved School).

(v) Sex education (Guardian - Counseling; Administration - Counseling; Counsellor Counseling; Administration-Administration duties)

Sex education is important for the children at risk particularly for those admitted to the institution due to related court cases. This is to prevent and protect them from being sexually harassed or abused. Some of the children are not fully aware and well-informed about sex education. There are cases of children being sexually active even before they entered the institution while some of them have limited knowledge about sex, and a few has already became a victim of sexual abuse. The caregivers need to have information on sexual education in order to guide and teach the children: "Normally, Community Welfare Assistants will find the information themselves on basic sexual education.. they will then informed and teach the children.." (Salman, Counsellor, S2, Boys' Approved School). 
A participant also mentioned that she refers to a nurse who works at the institution whenever she could not answer the children's question on sex: "The children sometimes ask... (I had a lot of boyfriends last time...and I have this problem) ... and we will provide answer whenever we can, however, for the questions that we cannot answer, we will refer to a nurse." (Zainab, Social Welfare Assistant, S9, Girls' Protection Shelter).

The caregivers even refer to other organizations to learn more about sex education: "in terms of HIV (Human Immunodeficiency Virus) and AIDS (Acquired Immune Deficiency Syndrome), we usually call PKN (Pusat Khidmat Nasihat) or KKM (Kementerian Kesihatan Malaysia or the Ministry of Health Malaysia) to come and brief the children." (Salman, Counsellor, S2, Boys' Approved School).

(vi) Monitoring of former children (Administration - Administration duties)

Caregivers are also required to monitor the children after they leave the institution. This is done by keeping in touch with the children and appoint them as mentors to the other children at the institution. Caregivers would gather information on education and career of the former children. The purpose of the monitoring process is not only to develop strong bond between the caregivers and the children who have already left the institution, but also to benefit the existing children in the institution: "Now, we keep track of the children... what are they (children) doing right now, what are their (children) jobs? We want them to become (children) mentors to their siblings here.." (Aisyah, Principal, S5, Children Shelter Home).

(vii) Disciplinary action towards children (Administration - Administration duties)

Caregivers need information related to disciplinary breach which require the right action, procedures and conflict resolutions. Throughout the corrective process, the principal, deputy principal and community welfare assistant need to get involved. Caregivers need to be informed on the disciplinary actions taken to the children. An example of a punishment as disciplinary action is taking away the children's special privileges: "For example, if there is a fight among the children which results in injuries, we will discuss and punish them accordingly.. the type of punishment may be that her (child at risk) privilege will be taken away." (Raziah, Social Welfare Assistant, S7, Girls' Protection Shelter).

The respondent even mentioned that they had to refer to the law act in order to acquire information about the institution's safety, especially in dealing with the children who had been involved in conflicts prior to their admission to the institution: "We only punish the wrongdoer, we also take action according to the law act. We lodge a police report and charge him (child at risk) for sexual misconduct for example, the outcome is depend on the court to decide. Normally, he (child at risk) will be transferred to other place." (Osman, Principal, S1, Boys' Approved School).

(viii) Sports information (Administration - Administration duties)

The institution offers extra curriculum activities outside the school compound for the children to join including sports activities. Some of the sports activities organized by the institution are in collaboration with external organizations to give the children opportunity to be involved in sports. For example, the football team at the Boys' Approved School is in collaboration with Kuala Lumpur Football Association to train selected children to be professional referees: "We deal directly with the Kuala Lumpur Football Association. They have agreed to conduct a referee programme for the children" (Osman, Principal, S1, Boys' Approved School). 
For the children who are interested to join a sport programme, the institution would gather their information: "We will ask those who are interested in football.." (Osman, Principal, S1, Boys' Approved School). The caregivers will then select the children based on a certain criteria. As such, the caregivers must first have information related to sports. "We filter them first.. one of the most important conditions is that he can read and write. He can understand terms and rules. We chose the best 10 candidates to sit for the exam... and all passed." (Salman, Counselor, S1, Boys' Approved School).

(ix) Safety information (Guardian-Supervision, Administration - Administration duties)

Safety is a high priority at the institutions as it is one of the important in maintaining a productive workplace. Similarly, it is a caregiver responsibility to ensure the safety of all residents in the institution. This statement shows that a safety briefing is conducted for the caregivers from time to time: "Oh, in terms of safety, the deputy principal will explain what we should do and observe, the important things among them are the children's safety, the patrol time of the caregivers, the children's schedule, and restricted areas of the children." (Salman, Counsellor, S1, Boys' Approved School).

A participant mentioned actions that caregivers have to take to ensure the safety of the institution: "...if anything happens, we refer to the police first. The police will come to take control." (Siddiq, Social Welfare Assistant, S4, Boys Approved School).

(x) Children's rewards (Counsellor-Parenting; Administration-Administration duties)

At the institutions, the children are be given rewards whenever they behave well throughout the monitoring process. There are many rewards given by the institutions to the children, including releasing them early rather than staying there for three years, getting to go to outing programmes, being allowed to call their parents, and involving in more activities outside. The monitoring system is important for the caregivers to know the children's attitude and behavior to decide if they are eligible for the reward. This is necessary as every officer needs to propose a few children's names along with their merits. If the children have successfully achieved the highest merits, they will be rewarded: "The responsible officer will assess and give merit to the trainer (the children). If they get the highest merit, they will be release early." (Ali, Social Welfare Assistant, S3, Boys' Approved School).

Outing programme is a session where the children go outside the institution for a visit or doing other activities. It is done in a group with the presence of the caregivers. The outing session is a reward for the children for their good deeds and it is a good practice to develop close relationship between the children and their caregivers. The caregivers commented that they needed information on a list of children who are eligible to join the outing programmes: "We will ask the case worker officers to name four or five people (children), and they will choose the best ones (children) to be brought out. It is actually a reward." (Osman, Principal, S1, Boys' Approved School).

(xi) Child Health (Guardian -Parenting)

A caregiver has the responsibility in taking care of the children's health and well-being. Some children however are in poor health conditions. For such cases the caregiver has to take care of a sick child, or send them to the clinic for medical treatment: "We (caregivers) refer him to the clinic when he is not well." (Siddiq, Social Welfare Assistant, FG1, Boys' Approved School). Another caregiver mentioned: "He (child at risk) will tell the officer (caregiver) who is on duty about his illness and we will give him (child at risk) some medication first.. However, if he is still sick, we will refer him to the clinic. If the clinic 
cannot give the appropriate medical attention, we normally refer him to the government hospital." (Ali, Social Welfare Assistant, FG1, Boys' Approved School).

As caregivers, the participants need to be alert about the children's health in order to ensure that the children receive appropriate treatment. For example, Aisyah indicated the need for caregivers to obtain information and be guided about HIV (Human Immunodeficiency Virus) and the correct medication dosage for the children: "We invite (health organization) twice a year to talk about health. Some of our community welfare assistants pursued their study in nursing, so when they (caregivers) do their community work here, they normally discuss with me on type of health courses that we should have.... we also talk about HIV since there are nine children here who are infected with HIV. The course is actually an additional health course for the community welfare assistants since they already had this knowledge. They need to be alert with the children's condition because sometimes the children need to change their medicine to a higher dose.. so, it is important for us to get the correct information." (Aisyah, Principal, S5, Children Welfare Home).

\section{DISCUSSION AND CONCLUSION}

The study is consistent with Noelker (2001) who shows formal caregivers as the backbone of the long-term care of children. They generally perform three vital roles as guardians counsellor, and administrator when taking care of the children at these institutions and in doing so, each of them involves in informational management roles as a monitor, disseminator and spokesperson respectively. The caregivers' roles involve taking care of the safety, health and day-to-day lifestyle of the children, as well as and providing information to them. The findings conform to a study by Omidire, Anna Mosia and Mampane (2015) on caregivers working at children homes where they are viewed as employees who perform rotational duties and take care of children at high ratios. This study's findings are also aligned with that of Czuba (2015) which posited that the main role of formal caregivers is to help people in their daily life activities. However, the findings also proved that there are caregivers who had no training prior to working as a child welfare assistant/officer. This creates a disadvantage to the caregiver while performing his/her responsibility.

From the results, it is obvious that formal caregiver wear many hats according to their roles. Each role is followed by several embedded tasks, including educating, parenting, supervising, counseling, and administrative duties. Each task involves informational management roles such as gathering relevant information, processing, analysing, disseminating and sharing information as well as using information for decision making. Caregivers who play the roles both as guardian and counsellor would look after the children's welfare through their daily activities, and partake in counseling, taking into consideration the children's background, health, safety, education, future, and career paths. Their tasks and responsibilities are huge and require full attention. According to Omidire, Anna Mosia and Mampane (2015), being a caregiver is not a simple job, but it gives the caregiver an opportunity to shape children's lives. Evidence show that this group of professionals faces growing demand due to the uniqueness of their services. Every task requires caregivers to have knowledge and information in order to justify their actions in performing their duties. As information providers, the guardian and counsellor are required to gather the information, process and disseminate the information among the children. 
As a mother or father to the children in these institutions, their role is to form close relationships with the children. As reported in the findings, children below 12 years old at the Children Welfare Home call their female caregiver "mother" and treat them like their parents. In the present study, the caregivers view themselves as parents to these children as they play a mother or father role to them. The female caregivers in this study are called "mother" which is is in line with findings by Neimetz (2010) where the orphans called their female caregiver "mother" and the male home manager "father". These caregivers' main roles are to provide care and support, but also information for the children. The findings also provide an indication that the caregivers do provide one-to-one attention to the children especially when they have problems, although each caregiver needs to take care of five to six children. Despite this, the researchers agreed that children at these institutions must be independent and need to compromise in terms of their development.

Although human infants are naturally fully dependent on parents for their life survival and development, children who are without parents such as those categorized as institutionalized children have to compromise on their own development (Dozier et al. 2012). It can be deduced from this study that caregivers understand that most of these children lack of or have never experienced parental care and nurturance. The caregivers in this study also seem to be comfortable in performing their informational roles and tasks. Hence, the caregivers play a vital role in helping the children to enhance their capabilities and gather information, and share the information with these children, especially on child development and independent life. Having ongoing warm relationships is very critical for the children to survive and develop healthily, more so in terms of food provision, stimulation, and child care (Hinde 1991; Rutter 1995).

Leckie, Pettigrew, and Sylvain's (1996) model has shown to be useful for investigating the information needs of formal caregivers at children welfare institutions, which covers their work roles and tasks. The information needs of formal caregivers are significant to justify their multiples roles at the institutions. The results of this study have shown that caregivers, like any other professionals, have numerous information needs. The information needs of caregivers are in relation to the roles they are responsible for especially in informational management roles. The caregivers in this study had expressed their needs, including those needed for their daily work lives and activities at these institutions. Other information needs are based on the children's situations in terms of their background, future education and career path, the monitoring of former children, disciplinary actions taken, health, sex education, rewards, sports information, and education. Since the objective of the caregivers included in the present study is to explain the need to obtain information about the children, it is clearly is in line with the findings by Lieberman (2011), Kiilu and Kiilu (2015), and Mnubi-Mchombu, Mostert and Ocholla (2009). These children, unlike other children who grow up with families at home, develop their own special needs while at the institutions. This process requires caregivers to acquire a wealth of information in order to fulfill the children's needs and to gather relevant information, processing, analyzing, disseminating and using information for decision making.

The findings of this study which were exploratory in nature and used the qualitative research approach, would be inappropriate to be generalized. Nevertheless, the findings had provided a better understanding of the informational roles and information needs of formal caregivers at children welfare institutions. Further studies to include a wider range of participants to find out the perspectives of the organization and top management could be considered to provide a more comprehensive understanding of the caregivers' informational needs based on their various roles. From another perspective, 
understanding the information needs from the lens of the children themselves would also beneficial to support the findings in a more holistic manner.

\section{ACKNOWLEDGEMENT}

The research was funded by the University of Malaya's research grant (BK007-2016). The authors would like to thank the Department of Social Welfare Malaysia for granting permission to conduct and complete the study at the three chosen institutions. The authors would also like to thank the reviewers for their careful reading of the manuscript and their many insightful comments and suggestions.

\section{REFERENCES}

Alavi, M., Boujarian, N. and Ninggal, M. T. 2012. The challenges of high school counsellors in work place. Procedia-Social and Behavioral Sciences, Vol. 46: 4786-4792. Available at: doi: 10.1016/j.sbspro.2012.06.335.

Arizona Board of Regents 2009. Policy Manual, Section 6-101. Conditions of Administrative Service. Arizona Board of Regents.

Audit Scotland. 2010. Getting it right for children in residential care. Available at: http://www.auditscotland.gov.uk/docs/local/2010/nr_100902_children_residential.pdf.

Choo, C.W. 2002. Information management for the intelligent organization: The art of scanning the environment (3rd ed.). Medford, NJ: Information Today, Inc.

Cohen, D., and Crabtree, B. 2006. Qualitative Research Guidelines Project. NJ: Robert Wood Johnson Foundation. Available at: http://www.qualres.org/HomeSemi-3629.html.

Cumming, J. M. 2011. Statistical modeling of caregiver burden and distress among informal caregivers of individuals with amyotrophic lateral sclerosis, Alzheimer's disease, and cancer Doctoral dissertation, Colorado State University. Available at: https://dspace.library.colostate.edu/bitstream/handle/10217/50673/Cumming_colostat e_0053A_10551.pdf?sequence $=1$.

Czuba, K. J. 2015. Understanding formal caregivers and work stress. Doctoral dissertation, Auckland University of Technology. Available at: https://aut.researchgateway.ac.nz/bitstream/handle/10292/9831/CzubaK.pdf?sequenc $\mathrm{e}=3$ \& isAllowed=y.

Department of Social Welfare (DSW) and UNICEF 2011. The Situation of Children in Residential Care Facilities in Myanmar. Available at: https://www.unicef.org/myanmar/Residential_Care_Survey_Report_-english.pdf.

Dozier, M., Zeanah, C. H., Wallin, A. R. and Shauffer, C. 2012. Institutional care for young children: Review of literature and policy implications. Social Issues and Policy Review, Vol 6, no 1: 1-25. Available at: doi: 10.1111/j.1751-2409.2011.01033.x.

Groark, C. J., and Mccall, R. B. 2011. Implementing changes in institutions to improve young children's development. Infant Mental Health Journal, Vol 32, no 5: 509-525. Available at: doi: 10.1002/imhj.20310.

Grove, C., Riebschleger, J., Bosch, A., Cavanaugh, D., and van der Ende, P. C. 2017. Expert views of children's knowledge need regarding parental mental illness. Children and Youth Services Review, Vol 79: 249-255. Available at: http://ezproxy.um.edu.my:2095/science/article/pii/S019074091730049X.

Heron, G., and Chakrabarti, M. 2002. Examining the perceptions and attitudes of staff working in community based children's homes: are their needs being met?. Qualitative Social Work, Vol 1, no 3: 341-358. Available at: doi:10.1177/147332500200100308. 
Hinde, R. A. 1991. Relationships, attachment, and culture: A tribute to John Bowlby. Infant Mental Health Journal, Vol 12, no 3: 154-163.

Hoghughi, M. S. and Long, N. 2004. Handbook of parenting: Theory and research for practice (Eds.). Thousand Oaks: CA: Sage.

Huckvale, T., and Ould, M. 1995. Process modelling-who, what and how: Role activity diagramming, in business process change: concepts, methods, and technologies. Harrisburg: Pa. Idea Group Pub.

Institutional care: The last resort (Policy Brief) 2014. London, United Kingdom: Save the Children. Available at: https://resourcecentre.savethechildren.net/library/institutionalcare-last-resort-policy-brief-2014.

Kadushin, A., and Harkness, D. 2014. Supervision in social work. New York, United States: Columbia University Press.

Kiilu, P. W., and Kiilu, V. B. 2015. Information access by Urban Social Workers in Kenya: A Case of Nakuru City. International Journal of Library Science, Vol 4, no 2: 35-42. Available at: http://article.sapub.org/10.5923.j.library.20150402.03.html.

Leckie, G. J., Pettigrew, K. E., and Sylvain, C. 1996. Modeling the information seeking of professionals: A general model derived from research on engineers, health care professionals, and lawyers. The Library Quarterly, Vol 66, no 2: 161-193.

Lexico Powered by Oxford. 2019. Available at: https://www.lexico.com/definition/ administration.

Lieberman, A. F. 2011. Trauma through the eyes of a young child. In Osofsky, J. D. Clinical work with traumatized young children (Eds.). New York, United States: Guilford Press. Available at: https://www.guilford.com/excerpts/osofsky3.pdf.

Malaysia. 1992. Child Protection Act, 1991 (Act 468); \& Akta Perlindungan Kanak-Kanak, 1991 (Akta 468) : as at 15th July 1992. Kuala Lumpur: International Law Book Services.

Marleen van Polanen, Cristina Colonnesi, Louis W. C. Tavecchio, Susanne Blokhuis and Ruben G. F. 2017. Men and women in childcare: a study of caregiver-child interactions. European Early Childhood Education Research Journal, Vol 25, no 3: 412-424. Available at: doi: 10.1080/1350293X.2017.1308165.

McCall, R. B. 2013. The consequences of early institutionalization: can institutions be improved? - should they? Child and Adolescent Mental Health, Vol 18, no 4: 193-201. Available at: http://doi/pdf/10.1177/147332500200100308.

McDonald, P., and Garrow, E. 2000. Reaching children in need: What's being done, what you can do. East Sussex, United Kingdom: Kingsway Publications.

Mintzberg, H. 1971. Managerial Work: Analysis from Observation. Management Science. INFORMS, Vol 18, no 2: B-97-B-110. Available at: doi: 10.1287/mnsc.18.2.B97.

Mnubi-Mchombu, C., Mostert, J., and Ocholla, D. 2009. Information needs and information-seeking behaviour of orphans and vulnerable children and their caregivers in Okahandja, Namibia. African Journal of Library, Archives and Information Science, Vol 19 , no 1.

Neimetz, C. 2010. Navigating family roles within an institutional framework: An exploratory study in one private Chinese orphanage. Journal of Child and Family Studies, Vol 20, no 5: 585-595.

Niedźwiedzka, B. 2003. A proposed general model of information behaviour. Information Research, Vol 9, no 1: 9-1.

Ndiku, M. T. 2015. An investigation of information needs of school children in Kibera informal settlements in Nairobi County, Kenya. Scholars Journal of Arts, Humanities and Social Sciences, Vol 3: 1429-1436.

Noelker, L. 2001. The backbone of the long-term-care workforce. Generations, Vol 25, no 1: 85-91. 
Omidire, M. F., Anna Mosia, D. and Mampane, M. R. 2015. Perceptions of the roles and responsibilities of caregivers in children's homes in South Africa. Revista de Asistenta Sociala, Vol 2: 113.

Ravenswood, K., Douglas, J. and Teo, S. 2014. The New Zealand aged care workforce survey 2014: A future of work programme report. Auckland, New Zealand: New Zealand Work Research Institute.

Rutter, M. 1995. Clinical implications of attachment concepts: Retrospect and prospect. Journal of Child Psychology and Psychiatry, Vol 36, no 4: 549-571.

Sukeri, S., Bakar, R. S., Othman, A. and Ibrahim, M. I. 2017. Barriers to unmet needs among mothers of children with disabilities in Kelantan, Malaysia: A qualitative study. Journal of Taibah University Medical Sciences, Vol 12, no 5: 424-429.

Team OncoLink. 2018. Caregiving: Roles and Tasks. OncoLink Penn Med. Available at: https://www.oncolink.org/support/caregivers/caregiving-roles-and-tasks accessed November 11, 2019.

UN General Assembly. 1989. Convention on the Rights of the Child. 20 November 1989. United Nations, Treaty Series, Vol 1577: 3. Available at: https://www.refworld.org/docid/3ae6b38f0.html [accessed 14 December 2019].

Utting, B., 1993. What social workers need: A general social services council, better education, and a wider range of employers. BMJ: British Medical Journal, Vol 306: 944945.

Utting, W. 1997. People Like Us: The report of the review of safeguards for children living away from home. London, England: The Stationery Office.

van IJzendoorn M.H., Palacios J, Sonuga-Barke E.J., Gunnar M.R., Vorria P., McCall R.B., LeMare L., Bakermans-Kranenburg M.J., Dobrova-Krol N.A. and Juffer F. 2011. Children in Institutional Care: Delayed Development and Resilience. Monograph of the Society for Research in Child Development, Vol 76, no 4: 8-30. Available at: doi: 10.1111/j.15405834.2011.00626.x.

Vakkari, P. 1999. Task complexity, problem structure and information actions: Integrating studies on information seeking and retrieval. Information Processing and Management, Vol 35, no 6: 819-837.

Wright, A. C., Lamsal, D., Ksetree, M., Sharma, A., and Jaffe, K. 2014. From maid to mother: Transforming facilities, staff training, and caregiver dignity in an institutional facility for young children in Nepal. Infant Mental Health Journal, Vol 35, no 2: 132-143.

Zoontjes, A. 2015. Information seeking behaviour of professionals: a qualitative study Master's thesis, University of Twente. 